\title{
The cellulase complex of Neurospora crassa: activity, stability and release
}

\author{
M. T. YAZDI, ${ }^{1} \dagger$ J. R. WoODWARD ${ }^{1}$ and A. RADFORD ${ }^{2 *}$ \\ Biotechnology Unit ${ }^{1}$ and Department of Genetics ${ }^{2}$, The University of Leeds, Leeds LS2 9JT, UK
}

(Received 11 December 1989; revised 1 March 1990; accepted 8 March 1990)

\begin{abstract}
The temperature and $\mathrm{pH}$ optima, and the temperature and pH stability, of crude and purified enzymes of the cellulase complex of the cellulolytic ascomycete fungus Neurospora crassa were investigated. The effects of some non-ionic surfactants and fatty acids on the production/release of enzymes of the cellulase complex were also examined. For the different enzymes of the complex, activity maxima occurred between pH 4.0 and 7.0, with pH 5.0 being close to optimal for stability of all. Temperature optima for activity ranged between 45 and $65^{\circ} \mathrm{C}$, with the stability optimum between 45 and $50{ }^{\circ} \mathrm{C}$. The presence of $\mathrm{C}_{18}$ fatty acids and surfactants resulted in increased production of both endoglucanase and exoglucanase in the medium. Oleic acid was the most effective fatty acid tested, and Tween 80 the most effective surfactant. Oleic acid had no detectable effect on production of $\beta$ glucosidase, and Tween $\mathbf{8 0}$ actually reduced its production.
\end{abstract}

\section{Introduction}

The cellulase complex of cellulolytic fungi consists of at least three extracellular enzymes: endoglucanase (EC 3.2 .1 .4 , endo-1,4- $\beta$-glucanase), exoglucanase (EC 3.2.1.91, 1,4- $\beta$-cellobiohydrolase) and $\beta$-glucosidase (EC 3.2.1.21). The majority of cellulase enzymes described so far have been from mesophilic bacteria and fungi. The most intensively studied cellulolytic fungus is Trichoderma reesei (Bisaria \& Ghose, 1981). The major problems in utilizing enzymes from mesophiles for production of fermentable substrates from cellulose are the low rate of hydrolysis achieved at the optimum growth temperature (Tansey, 1971), and the relatively poor thermal stability of the enzymes (Linko, 1977). One potential solution is the use of enzymes from thermophilic fungi. Recently an exoglucanase gene has been cloned and sequenced from the thermophilic fungus Humicola grisea var. thermoidea; it shows a close similarity to the equivalent enzyme from the mesophile T. reesei (Azevedo \& Radford, 1990). However, the higher optimum growth temperature of thermophiles is not necessarily reflected in the stability of their enzymes (Mandels, 1975).

In other species, it has been reported that surfactants and fatty acids stimulate production of the cellulase

$\dagger$ Present address: College of Pharmacy, Tehran University, Tehran, Iran.

Abbreviations: CMCase, carboxymethylcellulase ( $\equiv$ endoglucanase); FPA, filter paper activity ( $\equiv$ exoglucanase). complex (Reese \& Maguire, 1969; Reese et al., 1969; Shewale \& Sadana, 1978; Deshpande et al., 1987). The effect of fatty acids is thought to be mainly due to their incorporation into the cell membrane phospholipids, with consequent effects on cell permeability (Demain \& Birnbaum, 1968). The effect of surfactants has been attributed to at least three causes: $(a)$ action on the cell membrane causing increased permeability (Reese $e t$ al., 1969); $(b)$ promotion of the release of bound enzyme (Reese \& Maguire, 1969); (c) decrease in growth rate due to reduced oxygen supply (Hulme \& Stranks, 1970).

We have shown that Neurospora crassa is a true cellulolytic fungus capable of synthesizing and secreting high levels of the cellulase complex, and we have described optimization of induction and characterization of the enzymes (Yazdi et al., 1990a,b). N. crassa has the advantages of being the filamentous fungus most thoroughly characterized genetically (Perkins et al., 1982), and of having an efficient and well-characterized transformation system (Fincham, 1989). This paper extends our studies to the determination of $\mathrm{pH}$ and temperature optima for the cellulase enzymes of $N$. crassa, the stability of those enzymes, and the effects of surfactants and fatty acids on their production.

\section{Methods}

Culture conditions. Cellulase was produced by growing $N$. crassa strain cell-1 (FGSC no. 4335) in a medium containing $2 \%(w / v)$ microcrystalline cellulose (Sigma type 20), 2\% (v/v) Vogel's medium N salts solution (Vogel, 1964) and $0.75 \%$ yeast extract, at $\mathrm{pH} 7.0$ and 
$25^{\circ} \mathrm{C}$ in a 51 stirred, air-lift fermenter. After $8 \mathrm{~d}$ of growth, the supernate was separated by filtration $(10 \mu \mathrm{m}$ pore size). Immediately after separation, $0.5 \mathrm{ml} \mathrm{l}^{-1}$ of $50 \mathrm{mM}$-phenylmethylsulphonyl fluoride (PMSF) in propan-2-ol and $0.1 \mathrm{ml} \mathrm{l}^{-1}$ of $20 \mathrm{mM}-N$-tosyl-L-phenylalanine-chloromethyl ketone (TPCK) in propan-2-ol were added to inhibit protease activity. The enzymes were purified from the supernatant as described previously (Yazdi et al., $1990 \mathrm{~b}$ ).

Fatty acids and surfactants were added to flasks before autoclaving at 15 p.s.i. $(103.5 \mathrm{kPa})$ for $15 \mathrm{~min}$. Flasks were inoculated with $0.5 \mathrm{ml}$ volumes of conidial suspension (about $10^{7}$ conidia) made up in sterile distilled water . Cultures were grown in an orbital incubator, at $25^{\circ} \mathrm{C}$ and 200 r.p.m., for $12 \mathrm{~d}$.

Surfactants and fatty acids. The surfactants used were Tween 20 [polyoxyethylene (20) sorbitan monopalmitate], Tween 80 [polyoxyethylene (20) sorbitan monooleate], 'poly 10' [polyoxyethylene oleic acid (cis-9-octadecanoic acid), stearic acid (octadecanoic acid), X-100 (a proprietary polyoxyethylene ether), all obtained from Sigma. The fatty acids were capric acid (decanoic acid), myristic acid (tetradecanoic acid), linoleic acid (cis-9,cis-12-octadecadienoic acid), oleic acid (cis-9-octadecanoic acid), stearic acid (octadecanoic acid), and arachidonic acid (5,8,11,14-eicosatetraenoic acid), also from Sigma.

Enzyme assays. Activities of the three component types of the cellulase complex, endoglucanase (carboxymethylcellulase, CMCase), exoglucanase (filter paper activity, FPA) and $\beta$-glucosidase were assayed as described by Yazdi et al., $(1990 a)$. All assays were performed in duplicate. Enzyme activities are expressed in units, defined as $\mu \mathrm{mol}$ product liberated by the enzyme in $1 \mathrm{ml}$ of medium in either $15 \mathrm{~min}$ (for endoglucanase and $\beta$-glucosidase) or $60 \mathrm{~min}$ (for exoglucanase). Mycelial biomass was measured by the method of Margaritis \& Merchant (1986), and soluble protein by that of Bradford (1976).

For determination of temperature optima for activity, incubations were carried out at temperatures over the range $30-70^{\circ} \mathrm{C}$. For determination of $\mathrm{pH}$ optima, the enzymes were dissolved in distilled water, and mixed with equal volumes of $200 \mathrm{mM}$-phosphate/citrate buffer over the range $\mathrm{pH} 3 \cdot 0-9 \cdot 0$ prior to assay.

For enzyme thermal stability determination, enzyme preparations in $100 \mathrm{~mm}$-phosphate/citrate buffer at $\mathrm{pH} 5.0$ were incubated over the range $30-60^{\circ} \mathrm{C}$, samples being taken periodically for assay. For $\mathrm{pH}$ stability determination, enzyme solutions in $100 \mathrm{~mm}$-phosphate/citrate buffer at $\mathrm{pH}$ values between 3.0 and 8.0 were incubated over the range $30-60^{\circ} \mathrm{C}$. In all stability determinations, the maximum incubation time was $48 \mathrm{~h}$.

$S D S-P A G E$. Exported proteins were precipitated in acetone, centrifuged, and redissolved in $100 \mathrm{~mm}$-citrate buffer at $\mathrm{pH} 5.0$ to a concentration of $5-20 \mathrm{mg} \mathrm{ml}^{-1}$. Gel electrophoresis was in $10 \%(\mathrm{w} / \mathrm{v})$ polyacrylamide slab gels according to the method of Hames (1986). SDS and mercaptoethanol were used for denaturation.

\section{Results}

\section{Optimum temperatures for crude and purified enzymes}

Under the assay conditions used, the activity of $\beta$ glucosidase was optimal, in both crude and purified preparations, at $65^{\circ} \mathrm{C}$. Endoglucanase activity in crude preparations showed high activity over a wide range of temperature between 45 and $55^{\circ} \mathrm{C}$, with the optimum at $55^{\circ} \mathrm{C}$. Exoglucanase in crude preparations gave high activity between 45 and $55^{\circ} \mathrm{C}$, with the optimum above $50{ }^{\circ} \mathrm{C}$. Resuts are shown in Fig. 1(a).

The endo- and exoglucanase activities were both purified into their different isoenzymes, and each isoenzyme was found to have a distinct temperature profile. Among the endoglucanases, the activity profiles of which are given in Fig. $1(b)$, the optima were: endo-I, $55^{\circ} \mathrm{C}$; endo-II, $55^{\circ} \mathrm{C}$; endo-III, $50^{\circ} \mathrm{C}$; and endo-IV, $45^{\circ} \mathrm{C}$. The sum of these profiles is consistent with the very wide activity range of the crude extract. Activity ranges of the exoglucanases are shown in Fig. 1(c); the optima were: exo-I, $50{ }^{\circ} \mathrm{C}$; exo-II, $50{ }^{\circ} \mathrm{C}$; and exo-III, $55^{\circ} \mathrm{C}$. The temperature optimum for the purified $\beta$ glucosidase was initially $65^{\circ} \mathrm{C}$ as in the crude preparation, but decreased to $60^{\circ} \mathrm{C}$ after $30 \mathrm{~min}$.

These temperature optima for the $N$. crassa cellulase complex enzymes are compared with those of other cellulolytic organisms, both mesophiles and thermophiles, in Table 1. $N$. crassa $\beta$-glucosidase was comparable with the best of both mesophiles and thermophiles. $N$. crassa exoglucanases were comparable with those of other mesophiles. However, the $N$. crassa endoglucanases had comparatively low optima compared with those of the other species shown.

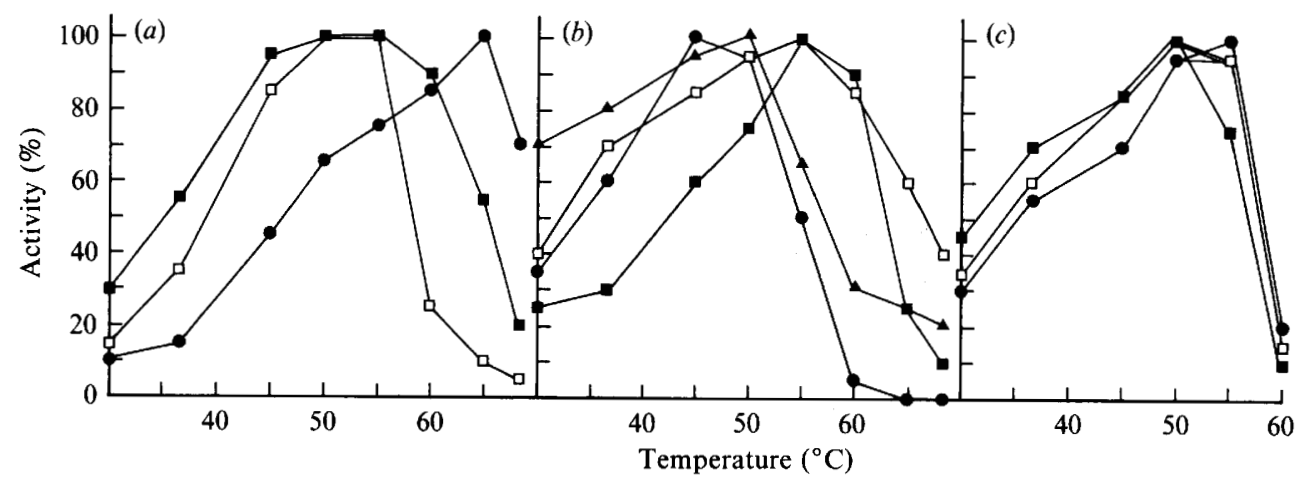

Fig. 1. Effect of temperature on the activity of cellulases from $N$. crassa. (a) Enzymes in crude preparation ( $\boldsymbol{\square}, \mathrm{CMCase;} \square, \mathrm{FPA} ; \boldsymbol{O}, \boldsymbol{\beta}$ glucosidase). (b) Purified endoglucanases ( $\square$, endo-I; $\square$, endo-II; $\boldsymbol{\Delta}$, endo-III; $\boldsymbol{O}$, endo-IV). (c) Purified exoglucanases ( $\square$, exo-I; $\square$, exo-II; 9 , exo-III). 


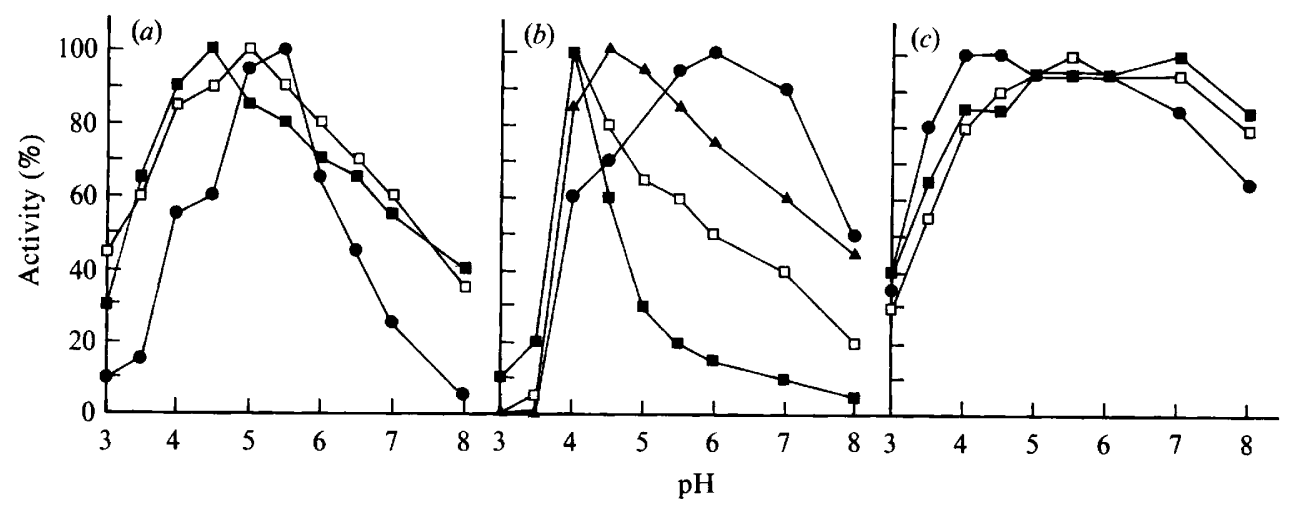

Fig. 2. Effect of pH on activity of cellulases from $N$. crassa. (a) Enzymes in crude preparation ( $\square$, CMCase; $\square$, FPA;,$\beta$-glucosidase). (b) Purified endoglucanases ( $\square$, endo-I; $\square$, endo-II; $\Delta$, endo-III, $\bullet$, endo-IV). (c) Purified exoglucanases ( $\square$, exo-I; $\square$, exo-II; $\bullet$, exo-III).

Table 1. Comparison of cellulolytic enzymes from $N$. crassa and other species

\begin{tabular}{lcccc}
\hline \hline & \multicolumn{3}{c}{ Optimal temp. for activity } & \\
\cline { 2 - 4 } \multicolumn{1}{c}{ Species } & CMCase & FPA & $\beta$-Glucosidase & Ref.* \\
\hline Neurospora crassa & 55 & 55 & 65 & \\
Trichoderma reesei & 60 & 55 & 65 & 1 \\
Penicillium sp. & 55 & 55 & 60 & 1 \\
Thielavia terrestris & 60 & 60 & 67 & 1 \\
Sporotrichum cellulophilum & 60 & 60 & 60 & 1 \\
Thermoactinomyces sp. & 70 & 65 & 55 & 2 \\
Chaetomium cellulolyticum & 55 & & 55 & 3 \\
Thermoascus auractiacus & 60 & 60 & 70 & 4 \\
\hline \hline
\end{tabular}

* References: 1, Durand et al. (1984); 2, Margaritis \& Merchant (1983); 3, Fahnrich \& Irrang (1982); 4, Tong et al. (1980).

\section{Thermal stability of the cellulolytic enzymes}

The total $N$. crassa endoglucanase activity in crude preparations was fairly stable over $48 \mathrm{~h}$ at temperatures up to $50^{\circ} \mathrm{C}$. At the temperature optimal for activity, approximately $20 \%$ of activity was lost over the first $12 \mathrm{~h}$, following which the level stabilized. The exoglucanase activity was fairly stable over $48 \mathrm{~h}$ at temperatures up to $45^{\circ} \mathrm{C}$, but declined significantly at higher temperatures, especially over the first $6 \mathrm{~h}$, dropping to approximately $70 \%$ at $50{ }^{\circ} \mathrm{C}, 60 \%$ at $55^{\circ} \mathrm{C}$ and $40 \%$ at $60^{\circ} \mathrm{C}$, after which it remained fairly stable in each case. With the multiplicity of isoenzymes for both endo- and exoglucanases, at least four of the former and three of the latter, the results are readily explicable. In each class, the multiphasic stability curve reflects the sum of activities of isoenzymes of different stabilities. $\beta$-Glucosidase activity was fairly stable over $48 \mathrm{~h}$ at temperatures up to $50{ }^{\circ} \mathrm{C}$, but was sensitive to higher temperatures, losing $80 \%$ of activity progressively over $36 \mathrm{~h}$ at $55^{\circ} \mathrm{C}$ and all activity after $24 \mathrm{~h}$ at $60^{\circ} \mathrm{C}$.

Although $N$. crassa has low temperature requirements for its production of the cellulase complex, in the range
23-25 ${ }^{\circ} \mathrm{C}$ (Yazdi et al., 1990a), thermal stability of these enzymes is certainly comparable to other mesophilic fungi (Coughlan, 1985; Durand et al., 1984; Margaritis \& Merchant, 1983). The half-life for its endo- and exoglucanases and $\beta$-glucosidase at $50^{\circ} \mathrm{C}$ was in excess of $48 \mathrm{~h}$.

\section{pH optima of crude and purified enzymes}

The optimal $\mathrm{pH}$ values for $N$. crassa cellulases were in the range $4 \cdot 5-5 \cdot 5$, with $\mathrm{pH} 4 \cdot 5$ optimal for crude endoglucanase, $\mathrm{pH} 5.0$ for exoglucanase and $\mathrm{pH} 5.5$ for $\beta$-glucosidase (Fig. 2a). For purified endoglucanases, optima were: endo-I, pH 4.0; endo-II, pH 4.0; endo-III, pH 4.5; and endo-IV, pH 6.0 (Fig. $2 b$ ). For the exoglucanases, $\mathrm{pH}$ optima for the purified enzymes were: exo-I, $\mathrm{pH} 7 \cdot 0$; exo-II, pH 6.0; and exo-III, pH 4.0 (Fig. 2c).

\section{Combined $p H$ and temperature effects on enzyme stability}

The stability of the $N$. crassa $\beta$-glucosidase and exoglucanase activities at temperatures up to $37^{\circ} \mathrm{C}$ was 
Table 2. Effect of various surfactants on extracellular levels of enzymes of the cellulase complex

None of these additives had a significant effect on growth

\begin{tabular}{|c|c|c|c|c|c|c|}
\hline \multirow[b]{2}{*}{ Additive } & \multicolumn{2}{|c|}{ Exoglucanase } & \multicolumn{2}{|c|}{ Endoglucanase } & \multicolumn{2}{|c|}{$\beta$-Glucosidase } \\
\hline & $\mathrm{U} \mathrm{ml}^{-1}$ & $\%$ of control & $\mathrm{U} \mathrm{ml}^{-1}$ & $\%$ of control & $\mathrm{U} \mathrm{ml}-1$ & $\%$ of control \\
\hline None & 75 & 100 & 305 & 100 & $5 \cdot 6$ & 100 \\
\hline Tween $20(0.1 \%)$ & 32 & 42 & 230 & 75 & $2 \cdot 5$ & 44 \\
\hline Tween $20(0.2 \%)$ & 75 & 100 & 310 & 101 & 3.6 & 65 \\
\hline Tween $80(0.2 \%)$ & 110 & 147 & 350 & 115 & $3 \cdot 3$ & 59 \\
\hline Brij $35(0 \cdot 1 \%)$ & 84 & 112 & 320 & 105 & $4 \cdot 2$ & 75 \\
\hline Brij $35(0.2 \%)$ & 95 & 125 & 350 & 115 & 3.9 & 69 \\
\hline
\end{tabular}

virtually independent of $\mathrm{pH}$ : the enzymes retained more than $90 \%$ of activity at any $\mathrm{pH}$ in the range $3 \cdot 5-9 \cdot 0$. Endoglucanase stability was pH-dependent even at low temperature, with optimum stability in the range pH 4.5-7.0.

At temperatures at or above $45^{\circ} \mathrm{C}$, the stability of all enzymes in the cellulase complex was $\mathrm{pH}$-dependent. For endoglucanase activity at $50^{\circ} \mathrm{C}$, stability was optimal at $\mathrm{pH} 5 \cdot 0$, but over the range $\mathrm{pH} 4 \cdot 0-7 \cdot 0$, about $70 \%$ of the activity was retained after $36 \mathrm{~h}$, falling to $40 \%$ at pH 8.0 . For exoglucanase activity at $55^{\circ} \mathrm{C}, 60 \%$ of activity remained at $\mathrm{pH} 4 \cdot 0-5.0$ after $36 \mathrm{~h}$, but this fell with increasing $\mathrm{pH}$ to only $25 \%$ at $\mathrm{pH} 8.0$. For $\beta$-glucosidase at $50{ }^{\circ} \mathrm{C}, 36 \mathrm{~h}$ activities were $90 \%$ at $\mathrm{pH} 5.0,75 \%$ at $\mathrm{pH} 4.0$ and $55 \%$ at $\mathrm{pH} 6.0$. At $\mathrm{pH} 7.0$, all $\beta$-glucosidase activity was lost after $24 \mathrm{~h}$.

\section{Effect of surfactants and fatty acids}

Of all the surfactants and fatty acids tested, only Triton $\mathrm{X}-100$ and 'poly 10 ', both at $0.1 \%$ had any inhibitory effect on growth of the mycelium. For all other compounds, growth was quantitatively and qualitatively. normai.

The effect of addition of surfactants on the production of the cellulase complex enzymes by $N$. crassa is shown in Table 2. Addition of Tween 80 gave the greatest improvement in production of extracellular exoglucanase. Similar levels of both Tween 80 and Brij 35 gave similar increases in endoglucanase production. All the surfactants tested sharply decreased $\beta$-glucosidase production.

To confirm that the influence of the surfactants on activity of the components of the cellulase complex was due to a direct effect on levels of synthesis of the enzymes, the supernate proteins were analysed by SDSPAGE; a densitometer tracing is shown for both control and Tween-80-treated cultures in Fig. 3. With Tween 80, a $76 \mathrm{kDa}$ peak ( $\beta$-glucosidase) was reduced to a shoulder as the activity of $\beta$-glucosidase was reduced by $41 \%$, and

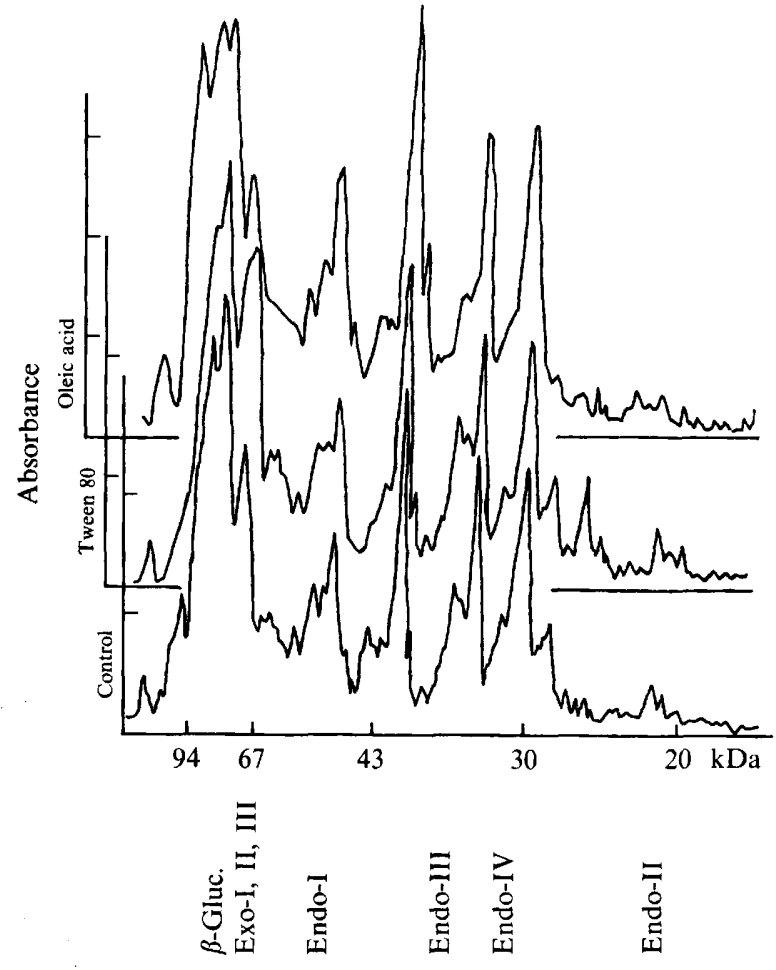

Fig. 3. Densitometer tracings of SDS-PAGE gels of exported proteins of control culture and cultures grown with the addition of $0.2 \%$ Tween 80 or $0.2 \%$ oleic acid. Locations of molecular mass markers and known enzymes of the cellulase complex are indicated.

an increase in the $69 \mathrm{kDa}$ peak (exo-I) correlated with a $47 \%$ increase in exoglucanase. Tween 80 also induced a band change not directly correlated with the size of any known member of the cellulase complex, an extra protein peak at $27 \mathrm{kDa}$. The effect of Tween 80 concentration was also investigated. A concentration of $2 \%(\mathrm{v} / \mathrm{v})$ was optimal for exoglucanase production, and $0.3-0.5 \%$ for endoglucanase production.

Addition of a variety of fatty acids at a concentration of $0.2 \%$ was investigated with respect to possible effects on production of the cellulase complex. The fatty acids 
Table 3. Effect of various fatty acids on extracellular levels of the enzymes of the cellulase complex

None of these additives had a significant effect on growth

\begin{tabular}{|c|c|c|c|c|c|c|}
\hline \multirow{2}{*}{$\begin{array}{c}\text { Additive } \\
(0.2 \%)\end{array}$} & \multicolumn{2}{|c|}{ Exoglucanase } & \multicolumn{2}{|c|}{ Endoglucanase } & \multicolumn{2}{|c|}{$\beta$-Glucosidase } \\
\hline & $\mathrm{U} \mathrm{ml} \mathrm{l}^{-1}$ & $\%$ of control & $\mathrm{U} \mathrm{ml}^{-1}$ & $\%$ of control & $\mathrm{U} \mathrm{ml}^{-1}$ & $\%$ of control \\
\hline None & 75 & 100 & 305 & 100 & $5 \cdot 6$ & 100 \\
\hline Capric & 38 & 49 & 190 & 65 & $4 \cdot 0$ & 70 \\
\hline Myristic & 29 & 39 & 95 & 31 & $3 \cdot 1$ & 56 \\
\hline Linoleic & 90 & 120 & 300 & 98 & 9.8 & 175 \\
\hline Oleic & 116 & 154 & 390 & 128 & $5 \cdot 5$ & 98 \\
\hline Stearic & 94 & 125 & 425 & 140 & 3.6 & 64 \\
\hline Arachidonic & 25 & 33 & 105 & 35 & 1.2 & 22 \\
\hline
\end{tabular}

and their carbon backbone lengths were capric acid $\left(\mathrm{C}_{10}\right)$, myristic acid $\left(\mathrm{C}_{14}\right)$, linoleic, oleic and stearic acids (all $\left.\mathrm{C}_{18}\right)$, and arachidonic acid $\left(\mathrm{C}_{20}\right)$. The results are given in Table 3 . In general only the $\mathrm{C}_{18}$ fatty acids gave any increase in production of endo- and exoglucanase activities, the best being a $50 \%$ increase in exoglucanase with oleic acid and a $40 \%$ increase in endoglucanase with stearic acid. All of the fatty acids, with the exception of linoleic acid which produced a $75 \%$ increase, and oleic acid which had no significant effect, produced a decrease in $\beta$-glucosidase activity. The effect of oleic acid concentration was investigated: concentrations of about $0.2 \%$ were optimal for production of the complex.

The effects of these fatty acids on protein concentrations in the supernate were investigated by SDS-PAGE, and a densitometer tracing of the results for oleic acid is shown in Fig. 3. As with the surfactant Tween 80, there were marked changes in level of a limited number of specific protein bands. With oleic acid there were changes in the sizes of peaks correlated with known enzymes of the cellulase complex, an increase in the $72 \mathrm{kDa}$ peak (the known size of exo-II and exo-III) with oleic acid correlating with a $54 \%$ increase in exoglucanase activity, and an increase in the $47 \mathrm{kDa}$ peak (endo-I) correlating with a $28 \%$ increase in endoglucanase activity. There was no change in either $\beta$-glucosidase or the corresponding $76 \mathrm{kDa}$ peak. There were also alterations in peaks not known to be directly correlated with members of the cellulase complex, the main ones being an increase in the peaks at about 110, 42 and $24 \mathrm{kDa}$, and a reduced peak at $28 \mathrm{kDa}$.

Addition of any of the fatty acids or detergents, at concentrations used in any of the experiments described, directly to the enzyme preparations had no effect on their activity.

\section{Discussion}

The study of $\mathrm{pH}$ and temperature characteristics of the $N$. crassa cellulase complex has confirmed the isoenzymes postulated earlier (Yazdi et al., 1990b), as the four endoglucanases and three exoglucanases defined initially on the basis of molecular mass and extent of glycosylation have now been shown to be distinct also in $\mathrm{pH}$ and temperature activity optima and stabilities. The present data on $\beta$-glucosidase are consistent with the single enzyme species postulated earlier.

The three activity classes of the $N$. crassa cellulase complex show a wide $\mathrm{pH}$ range and a fairly high optimum temperature for activity, and good thermostability.

It is clear from the results presented that, under certain conditions, some fatty acids and surfactants elicit an increase in the amounts of certain of the enzymes of the cellulase complex in the medium. The effect of a surfactant such as Tween 80 , and of those positively acting fatty acids, may be due to an increase in the permeability of the cell membrane, thus permitting more of the enzymes to be secreted, as postulated for other species by Reese \& Maguire (1969) and Demain \& Birnbaum (1968). However, this would not explain the dramatic effect of the addition of linoleic acid on $\beta$ glucosidase activity.

The positive effect on cellulase production by oleic acid and Tween 80 was only found on endo- and exoglucanases, and Tween 80 actually decreased the $\beta$ glucosidase level. This may imply some difference in the means by which the two glucanases and $\beta$-glucosidase are released. In most organisms studied, $\beta$-glucosidase is an intracellular enzyme, released only by autolysis of the producing cells (Gong \& Tsao, 1979). Substrates such as cellobiose are soluble and potentially transportable, and so do not require enzymes for their utilization to be extracellular.

Rather than oleic acid and Tween 80 having a depressive effect on autolysis, the increase in exo- and endoglucanase but not $\beta$-glucosidase could be explained by changes in membrane fluidity, as the number of double bonds present in a fatty acid determines its melting point, and hence has an effect on membrane fluidity. 
In general, changing the fluidity of the membrane is seen to substantially affect the passage of ions and small molecules through their appropriate transport systems. There has been little work on the effect of these changes in membrane content on protein translocation across the membrane. However, the presence of detergents and changes in fatty acid composition clearly perturb the membrane composition and fluidity, and physical as well as biochemical parameters of membrane function. The selective increase in secretion of some of the cellulase complex enzymes might well be explained by subtle changes in those parts of the membrane which are normally fluid. The selective nature of this secretion suggests that protein secretion is intimately linked to membrane lipid composition. The observation that certain non-cellulase protein peaks also change under the influence of surfactants and fatty acids, while certain members of the cellulase complex do not, is evidence that their effect is not specifically on the cellulase complex, but on protein secretion in general.

The effect of changes in membrane lipid components on the activity of membrane-bound proteins is well known (Hunter \& Rose, 1972; Rattray et al., 1975). Many authors have noted changes in the transport of amino acids and sugars associated with changes in cell membrane composition. The most dramatic of these effects is the death of Saccharomyces cerevisiae mutants incapable of synthesizing inositol, and hence phosphatidylinositol, under which conditions the cell membrane becomes permeable to cell constituents (Ulaszewski et al., 1978). Fatty acid starvation of yeasts also causes cell death (Henry, 1973). Similar effects have been reported in $N$. crassa (Statkin \& Tatum, 1961; Sullivan \& DeBusk, 1973). Less dramatic effects on the alteration of membrane lipid composition were reported in Fusarium by Miller \& Bairan (1984). These authors also noted increases in permeability to water and amino acids on addition of low concentrations of cationic detergents.

It is possible that the secretion mechanism differs between the various enzymes of the cellulase complex. For example, oleic acid has the greatest effect on exoglucanase activity in the medium, stearic acid on endoglucanase, and linoleic acid on $\beta$-glucosidase. This means that a membrane rich in stearic acid, having more rigidity and less fluidity, might favour endoglucanase secretion. Conversely, the most fluid membrane, with an enhanced linoleic acid content, might favour $\beta$-glucosidase secretion. The effect of Tween 80 would be similar to that of the fatty acids, effecting changes in the cell membrane. It seems unlikely that the effects noted here are due to changes in the growth patterns of the fungus, especially as there was no change in the overall growth rate of the mycelium on addition of any of these compounds.
The negative effect of higher concentrations of Tween 80 and oleic acid becomes detectable at levels where the surfactant or fatty acid could well provide the major carbon source for the organism, thus providing a possible indirect mode of action via carbon catabolite repression.

\section{References}

Azevedo, M. DE O. \& Radford, A. (1990). Sequence of $c b h-1$ gene of Humicola grisea var. thermoidea. Nucleic Acids Research 18, 668.

BisARIA, V. S. \& GHOSE, T. K. (1981). Biodegradation of cellulosic material: substrates, microorganisms, enzymes and products. Enzyme and Microbial Technology 3, 90-104.

BRADFORD, M. M. (1976). A rapid and sensitive method for the quantitation of microgram quantities of protein utilising the principle of protein-dye binding. Analytical Biochemistry 72, 248254.

Coughlan, M. P. (1985). The properties of fungal and bacterial cellulases with comment on their production and application. Biotechnology and Bioengineering Reviews 3, 39-109.

Demain, A. L. \& Birnbaum, J. (1968). Alteration of permeability for the release of metabolites from microbial cells. Current Topics in Microbiology and Immunology 46, 1-25.

Deshpande, M. V., Srinavasan, M. C. \& Deshmakh, S. S. (1987). Effect of fatty acids on cellulase production by Penicillium funiculosum and its mutants. Biotechnology Letters 9, 301-304.

Durand, H., Soucaille, P. \& TIRABY, G. (1984). Comparative study of cellulases and hemicellulases from four fungi. Enzyme and Microbial Technology 6, 175-180.

FAHNRICH, P. \& IRRANG, K. (1982). Some characteristics of the cellulolytic enzyme system of Chaetomium cellulolyticum. Biotechnology Letters 4, 519-524.

FinchAM, J. R. S. (1989). Transformation in fungi. Microbiological Reviews 53, 148-170.

Gong, C. S. \& TsaO, G. T. (1979). Cellulase biosynthesis and regulation. Annual Reports on Fermentation Processes 3, 111-140.

Hames, B. D. (1986). In Gel Electrophoresis of Proteins - a Practical Approach, pp. 1-86. Edited by B. D. Hames \& D. Rickwood. Oxford: IRL Press.

HENRY, S. (1973). Death resulting from fatty acid starvation in yeast. Journal of Bacteriology 136, 49-54.

Hulme, M. A. \& StranKs, D. W. (1970). Induction and the regulation of production of cellulase by fungi. Nature, London 226, 469-470.

HUNTER, K. \& RosE, A. H. (1972). Lipid composition of Saccharomyces cerevisiae as influenced by growth temperature. Biochimica et Biophysica Acta 260, 639-653.

LiNKo, M. (1977). An evaluation of enzymatic hydrolysis of cellulosic materials. Advances in Biochemical Engineering 5, 25-48.

MANDELS, M. (1975). Microbial sources of cellulase. Biotechnology and Bioengineering Symposium 5, 81-105.

Margaritis, A. \& Merchant, R. F. (1983). Production and thermal stability characteristics of cellulase and xylanase enzymes from Thielavia terrestris. Biotechnololgy and Bioengineering Symposium 13, 299-314.

Margaritis, A. \& Merchant, R. F. (1986). Optimisation of fermentation conditions for thermostable cellulase production by Thielavia terrestris. Journal of Industrial Microbiology 1, 149-156.

MilleR, R. W. \& Bairan, L. R. (1984). Control of membrane fluidity in Fusarium. Biomembranes 12, 433-450.

Perkins, D. D., Radford, A., Newmeyer, D. \& BJörkman, M. (1982). Chromosomal loci of Neurospora crassa. Microbiological Reviews 46, 426-570.

RatTRAY, J. B. M., SchiheCI, A. \& KIDBY, D. K. (1975). Lipids of yeasts. Bacteriological Reviews 39, 197-231.

REESE, E. T. \& MAGUiRe, A. (1969). Surfactants as stimulants of enzyme production by microorganisms. Applied Microbiology 17, 242-245. 
Shewale, J. G. \& Sadana, J. C. (1978). Cellulase and $\beta$-glucosidase production by basidiomycete species. Canadian Journal of Microbiology 24, 1204-1216.

Statkin, A. J. \& TATUM, E. L. (1961). The relationship of $m$-inositol to morphology in Neurospora crassa. American Journal of Botany 48, 760-771.

Sullivan, J. L. \& DeBusk, A. G. (1973). Inositolless death in Neurospora and cellular ageing. Nature New Biology 243, 72-74.

TANSEY, M. R. (1971). Agar diffusion assay for cellulolytic ability of thermophilic fungi. Archives of Microbiology 77, 1-11.

TONG, C. C., Cole, A. L. \& ShePherd, M. G. (1980). Purification and properties of cellulase from the thermophilic fungus Thermoascus auractiacus. Biochemical Journal 191, 83-94.
Ulaszewski, S., WoOdWard, J. R. \& Cirillo, V. P. (1978). Membrane damage associated with inositol-less death in Saccharomyces cerevisiae. Journal of Bacteriology 136, 49-54.

VoGEL, H. J. (1964). Distribution of lysine pathways among fungi: evolutionary implications. American Naturalist 98, 435-446.

YAZDI, M. T., WoOdWARD, J. R. \& RADFoRd, A. (1990a). Cellulase production by Neurospora crassa: induction and optimisation of the enzyme complex. Enzyme and Microbial Technology 12, 116-119.

YAZDI, M. T., RADFord, A., KEEN, J. N. \& WoODWARD, J. R. (1990b). Cellulase production by Neurospora crassa. Purification and characterisation of cellulolytic enzymes. Enzyme and Microbial Technology 12, 120-123. 